\title{
Pengaruh ukuran Pemda, leverage dan kinerja Keuangan terhadap IFR pada Pemda dengan Dimoderasi Opini Audit
}

\author{
Shanti R. H. Nufus ${ }^{1}$ \\ Fakultas Ekonomi dan Bisnis \\ Universitas Mataram, Indonesia. \\ Email: Nufusshanti@gmail.com
}

\author{
Titiek Herwanti² \\ Fakultas Ekonomi dan Bisnis \\ Universitas Mataram, Indonesia.
}

\section{Budi Santoso ${ }^{3}$ \\ Fakultas Ekonomi dan Bisnis Universitas Mataram, Indonesia.}

\begin{abstract}
ABSTRAK
Penelitian bertujuan memberikan bukti secara empiris mengenai pengaruh ukuran pemda, leverage, dan kinerja keuangan terhadap Internet Financial Reporting (IFR) pada pemda di Indonesia serta pengaruh opini audit dalam hubungan antara ukuran pemda, leverage, dan kinerja keuangan terhadap IFR pada pemda di Indonesia. Populasi penelitian adalah seluruh Pemerintah Kabupaten/Kota di Indonesia. Sampel diambil secara purposive sampling dan berjumlah 203 pemda. Hasil penelitian menunjukkan ukuran pemda dan kinerja keuangan berpengaruh positif dan signifikan terhadap IFR, leverage berpengaruh positif, tetapi tidak signifikan terhadap IFR. Opini audit berpengaruh positif, tetapi tidak signifikan terhadap hubungan ukuran pemda dengan IFR serta opini audit berpengaruh negatif, tetapi tidak signifikan terhadap hubungan leverage dan kinerja keuangan dengan IFR.
\end{abstract}

Kata Kunci : Internet Financial Reporting; Ukuran Pemda; Leverage; Kinerja; Opini.

The effect of government size, leverage and financial performance on IFR in local governments moderating by audit opinions

\begin{abstract}
This study aims to provide empirically the effect of size, leverage, and financial performance on Internet Financtal Reporting (IFR) and the influence of audit opinion in relations between size, leverage and financial performance on IFR in local governments in Indonesia. Population in this research is all District and City in Indonesia. Samples were taken by purposive sampling, 203 local governments was obtained. The results show that size and financial performance has a positive and significant effect on IFR, leverage has a positive but not significant effect on IFR. Audit opinion has a positive but not significant effect to the relationship between size with the IFR, audit opinion has a negative but not significant effect on the relationship between leverage and financial performance with the IFR.
\end{abstract}

Keywords: Internet Financtal Reporting, Government Size, Leverage, Financial Performance, Audit Opinion.

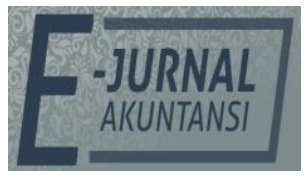

E-JA

e-Jurnal Akuntansi e-ISSN 2302-8556

Vol. 29 No. 3

Denpasar, Desember

2019

Hal. 1012-1025

Artikel masuk: 03 September 2019

Tanggal diterima: 18 November 2019 


\section{PENDAHULUAN}

Transparansi dan ketersediaan informasi sektor publik di Indonesia semakin meningkat sejak dikeluarkannya Undang-Undang Republik Indonesia No. 14 Tahun 2008 tentang Keterbukaan Informasi Publik. Salah satu bentuk transparansi yang dapat dilakukan oleh pemerintah daerah adalah pelaporan keuangan melalui website. Pemerintah mengeluarkan Instruksi Mendagri No. 188.52/179/SJ Tahun 2012 tentang Peningkatan Transparansi Pengelolaan Anggaran Daerah (TPAD) yang mengamanatkan pemerintah daerah untuk menyiapkan menu konten dengan nama TPAD dalam website resmi masingmasing pemerintah provinsi dan mempublikasikan 12 dokumen pengelolaan anggaran daerah kepada masyarakat di dalam situs resminya.

Pelaporan keuangan melalui media website pemerintah dikenal dengan Internet Financial Reporting (IFR). Pemilihan website sebagai sarana publikasi informasi keuangan daerah mempunyai keunggulan dimana website memberikan kemudahan akses sehingga data akuntansi secara elektronik dapat diakses kapanpun dan dimanapun (Xiao, Jones, \& Lymer, 2005). Oleh karena itu, pemanfaatan website pemerintah daerah dapat membuat pertanggungjawaban pengelolaan keuangan daerah menjadi lebih efektif dan efisien. Namun pada prakteknya, belum semua pemerintah daerah memiliki website resmi aktif yang terpelihara baik dilihat dari sisi muatan maupun berita terkini meskipun telah ada regulasi yang mengatur tentang website pemerintah daerah. Selain itu, pemerintah daerah yang telah memiliki website resmi pun belum semuanya menerbitkan laporan keuangan pada website masing-masing. Dari 508 pemerintah daerah yang memiliki kekuasaan otonom di Indonesia, terdapat 37 pemerintah kabupaten/kota yang belum memiliki website resmi dan hanya 417 website yang bisa diakses pada tahun 2017 (Purwanti, 2017). Namun, pada tahun 2018 tercatat 93,31 persen atau 474 pemerintah daerah kabupaten/kota di Indonesia telah memiliki website resmi (Kholifah, 2019). Dari 474 website kabupaten/kota di Indonesia, website pemerintah kabupaten/kota yang menyediakan menu konten TPAD sesuai dengan Instruksi Mendagri No. 188.52/179/SJ Tahun 2012 hanya berjumlah 208 pemerintah kabupaten/kota atau 54,32 persen.

Ada banyak penelitian terdahulu yang meneliti tentang faktor-faktor yang mempengaruhi IFR baik pada sektor swasta maupun pemerintah. Beberapa diantaranya adalah penelitian (Sinaga \& Probowo, 2011), (Medina, 2012), (Sutaryo, Rahman, \& Budiatmanto, 2013), (Trisnawati \& Achmad, 2014), (Verawaty, 2015), serta (Nosihana \& Yaya, 2016). Dari penelitian-penelitian terdahulu diketahui faktor-faktor yang mempengaruhi IFR, beberapa diantaranya adalah ukuran pemda, leverage dan kinerja keuangan. Penelitianpenelitian terdahulu masih menunjukkan hasil yang tidak konsisten tentang pengaruh ukuran pemda, leverage, dan kinerja keuangan terhadap Internet Financial Reporting. Ketidakkonsistenan hasil penelitian tersebut kemungkinan dipengaruhi oleh variabel-variabel lain yang dapat bertindak sebagai variabel moderasi.

Penelitian ini mencoba memasukkan variabel opini audit sebagai variabel moderasi ke dalam model penelitian. Menurut Badjuri dan Trihapsari (2004) dalam (Hiola, Rosidi, \& Mulawarman, 2015) tuntutan masyarakat agar organisasi 
sektor publik dapat meningkatkan kualitas, profesionalisme dan akuntabilitas publik dalam menjalankan programnya mendorong dilakukannya audit yang tidak hanya sebatas kepatuhan tetapi juga terhadap kinerja. Laporan keuangan pemda yang telah diaudit oleh BPK dan mendapatkan opini wajar tanpa pengecualian dapat mendorong kepatuhan pemda dalam mengungkapkan informasi keuangan di website. Oleh karena itu, penelitian ini ingin menganalisis dan memberikan bukti secara empiris mengenai pengaruh ukuran pemerintah daerah, leverage, dan kinerja keuangan daerah terhadap Internet Financial Reporting pada pemerintah daerah di Indonesia serta pengaruh opini audit dalam memperkuat hubungan antara ukuran pemerintah daerah, leverage, dan kinerja keuangan daerah terhadap Internet Financial Reporting pada pemerintah daerah di Indonesia. Penggunaan opini audit sebagai variabel moderasi merupakan kebaruan dari penelitian ini.

Berdasar riset gap tersebut maka rumusan permasalahan dalam penelitian ini adalah: 1. Apakah terdapat pengaruh ukuran pemerintah daerah, leverage, dan kinerja keuangan daerah terhadap Internet Financial Reporting pada pemerintah daerah di Indonesia?; 2. Apakah terdapat pengaruh opini audit dalam memperkuat hubungan antara ukuran pemerintah daerah, leverage, dan kinerja keuangan daerah dengan Internet Financial Reporting pada pemerintah daerah di Indonesia?

Berdasarkan rumusan masalah yang telah diuraikan, maka tujuan penelitian ini adalah untuk menganalisis dan memberikan bukti secara empiris mengenai pengaruh ukuran pemerintah daerah, leverage, dan kinerja keuangan daerah terhadap Internet Financial Reporting pada pemerintah daerah di Indonesia serta pengaruh opini audit dalam memperkuat hubungan antara ukuran pemerintah daerah, leverage, dan kinerja keuangan daerah terhadap Internet Financial Reporting pada pemerintah daerah di Indonesia.

Kerangka konseptual dalam penelitian ini berangkat dari stewardship theory yang menggambarkan situasi dimana manajemen tidaklah termotivasi oleh tujuan-tujuan individu tetapi lebih ditujukan pada sasaran hasil utama mereka untuk kepentingan organisasi (Donaldson \& Davis, 1991). Stewardship theory dalam penelitian ini digunakan untuk menjustifikasi hubungan antara masyarakat sebagai principal dan pemerintah daerah sebagai steward dimana pemerintah daerah diharapkan dapat mewujudkan transparansi terhadap rakyat sesuai harapan dan kepercayaan yang telah diberikan rakyat.

Pengungkapan informasi keuangan yang disajikan secara lengkap menunjukkan inisiatif bagi pemerintah daerah tersebut untuk lebih transparan dalam pengelolaan pemerintahannya yang akan berujung balasan signal yang baik dari masyarakat yang akan terus mendukung pemerintah untuk terus berkembang dan optimal dalam membangun negara. Hal ini sejalan dengan konsep signalling theory yang menggambarkan berbagai sinyal yang disampaikan oleh pemerintah sebagai pengemban amanat kepada masyarakat yang memberikan amanat. Bentuk pertanggungjawaban kepada masyarakat yang paling efisien, cepat dan murah adalah publikasi laporan keuangan melalui internet atau Internet Financial Reporting.

Secara sistematis rerangka konseptual penelitian ini dapat dilihat pada Gambar 1 sebagai berikut : 


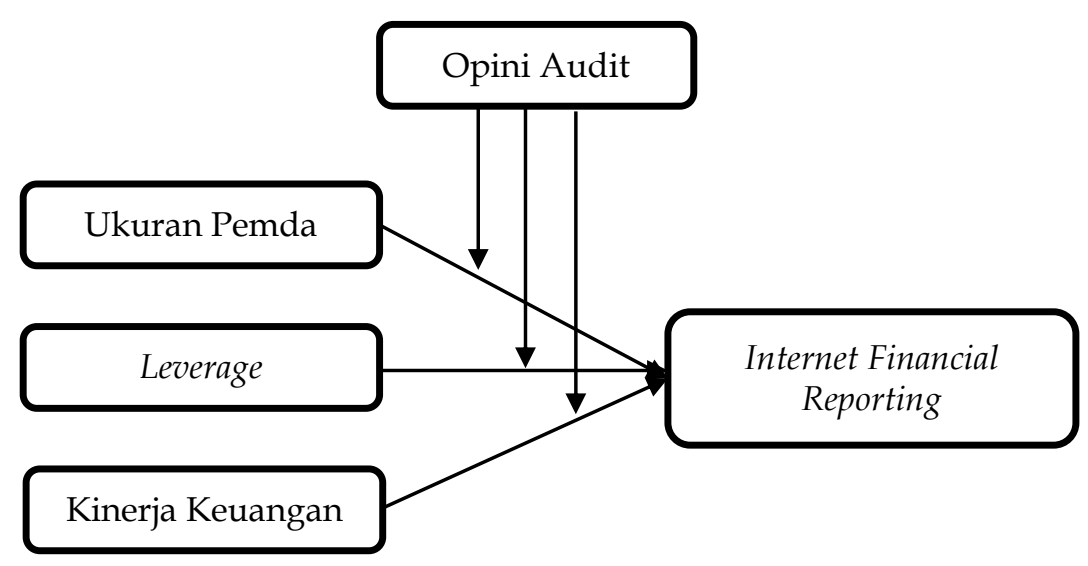

Gambar 1. Model Penelitian

Sumber: Data Penelitian, 2019

Pemerintah daerah yang besar umumnya memiliki jumlah kekayaan yang besar pula sehingga pengawasan terhadap kegiatan pemerintah semakin ketat. Publikasi laporan keuangan merupakan salah satu bentuk sinyal positif yang dapat diberikan oleh pemerintah. Pengungkapan informasi keuangan yang disajikan secara lengkap menunjukkan inisiatif bagi pemerintah daerah tersebut untuk lebih transparan dalam pengelolaan pemerintahannya. Melalui internet, pemerintah daerah dapat memberikan informasi keuangan secara cepat dengan biaya rendah, sehingga kebutuhan pelaporan terpenuhi dan biaya yang dikeluarkan dapat dikurangi (Trisnawati \& Achmad, 2014). Hal ini didukung oleh penelitian (García \& García-García, 2010), (Medina, 2012), (Trisnawati \& Achmad, 2014) dan (Diani, 2016) yang menemukan bahwa ukuran pemerintah daerah berpengaruh terhadap IFR. Berdasarkan penjelasan tersebut, maka dapat ditarik hipotesis sebagai berikut:

$\mathrm{H}_{1}$ : Ukuran pemerintah daerah berpengaruh positif terhadap Internet Financial Reporting pada Pemerintah Daerah di Indonesia.

Leverage yang tinggi akan menuntut pemerintah untuk menyediakan media pengawasan bagi kreditur untuk mengawasi penggunaan dana yang dipinjam serta memonitor kesanggupan pemerintah dalam melunasi hutang. Internet Financial Reporting dapat menjadi media pengawasan yang tepat yang dapat disediakan oleh pemerintah bagi kreditur karena dapat diakses dimana saja dan kapan saja serta hemat biaya. Penelitian (Laswad, Fisher, \& Oyelere, 2005) menemukan bahwa Internet Financial Reporting dapat diprediksi berdasarkan leverage. Penelitian (García \& García-García, 2010), (Sutaryo et al., 2013) serta (Trisnawati \& Achmad, 2014) juga menemukan bahwa leverage berpengaruh positif terhadap Internet Financial Reporting. Berdasarkan penjelasan di atas dan hasil-hasil penelitian sebelumnya, maka hipotesis yang diajukan:

$\mathrm{H}_{2}$ : Leverage berpengaruh positif terhadap Internet Financial Reporting pada Pemerintah Daerah di Indonesia.

Kinerja keuangan pemerintah daerah menggambarkan kemampuan daerah dalam menggali dan mengelola sumber-sumber keuangan asli daerah secara maksimal guna membiayai berjalannya sistem pemerintahan, pelayanan kepada masyarakat, dan pembangunan daerah. Kinerja keuangan pemerintah daerah menggambarkan tingkat kemandirian daerah. Pemerintah daerah yang memiliki 
kinerja yang buruk akan menghindari pengungkapan dan akan lebih memilih untuk membatasi akses informasi untuk masyarakat (Craven dan Marston, 1999). Hal ini didukung oleh penelitian (Hiola et al., 2015) yang menunjukkan bahwa kinerja keuangan berpengaruh terhadap kepatuhan pengungkapan informasi keuangan di website pemerintah daerah. Berdasarkan penjelasan tersebut, maka hipotesis yang diajukan:

$\mathrm{H}_{3}$ : Kinerja keuangan berpengaruh positif terhadap Internet Financial Reporting pada Pemerintah Daerah di Indonesia.

Ukuran pemerintah daerah dapat dilihat dari sumber daya atau kekayaan yang dimiliki daerah. Kemampuan pemerintah daerah dalam mengelola sumber daya yang dimiliki daerah akan tertuang dalam laporan keuangan pemerintah daerah. (Styles \& Tennyson, 2007) berpendapat bahwa pemerintah daerah yang mendapat penghargaan dari organisasi eksternal atas praktek pelaporan keuangan yang baik, cenderung untuk menyajikan laporan keuangannya di internet. Oleh karena itu, pemerintah daerah yang besar apabila mendapatkan opini audit yang baik akan semakin terdorong untuk mengungkapkan informasi keuangan di website pemerintah daerah. Opini audit yang baik dapat memperkuat hubungan antara ukuran pemerintah daerah dengan Internet Financial Reporting. Dari uraian tersebut dapat dikemukakan hipotesis sebagai berikut :

$\mathrm{H}_{4}$ : Opini audit memperkuat pengaruh ukuran pemerintah daerah terhadap Internet Financial Reporting pada Pemerintah Daerah di Indonesia.

Leverage menggambarkan kemampuan pemerintah daerah dalam menjamin dana yang dipinjam menggunakan jumlah aset yang dimiliki oleh pemerintah daerah. Pemerintah dengan leverage tinggi akan mendapatkan pengawasan yang lebih tinggi dari pihak kreditur. Internet dapat digunakan pemerintah daerah sebagai fasilitas pengawasan yang disediakan bagi kreditur. Pemerintah daerah akan lebih terdorong untuk mengungkapkan laporan keuangan melalui internet (Internet Financial Reporting) apabila mendapatkan opini audit yang baik seperti Wajar Tanpa Pengecualian. (Wau \& Ratmono, 2015) dan (Wulandari \& Sulardi, 2018) menemukan bahwa opini audit yang diperoleh oleh pemerintah daerah berpengaruh terhadap ketersediaan IFR pada website pemerintah daerah. Oleh karena itu, maka dapat dikemukakan hipotesis sebagai berikut :

$\mathrm{H}_{5}$ : Opini audit memperkuat pengaruh leverage terhadap Internet Financial Reporting pada Pemerintah Daerah di Indonesia.

Opini audit yang baik diperoleh dari kinerja pemerintahan yang baik dan merupakan gambaran dari pengelolaan keuangan daerah yang tertib oleh pemerintah (Hiola et al., 2015). Oleh karena itu, opini audit yang wajar dapat memperkuat pengaruh kinerja keuangan dengan Internet Financial Reporting pada pemerintah daerah. Penelitian (Hiola et al., 2015) menemukan bahwa opini audit dapat memoderasi pengaruh kinerja keuangan terhadap kepatuhan pengungkapan informasi keuangan pemerintah daerah di website. Berdasarkan paparan tersebut maka hipotesis yang diajukan adalah:

$\mathrm{H}_{6}$ : Opini audit memperkuat pengaruh kinerja keuangan terhadap Internet Financial Reporting pada Pemerintah Daerah di Indonesia. 


\section{METODE PENELITIAN}

Jenis penelitian yang digunakan yaitu penelitian eksplanatori. Penelitian ini dilakukan pada masing-masing website pemerintah kota dan kabupaten di Indonesia. Populasi dalam penelitian ini adalah seluruh pemerintah kota dan kabupaten di Indonesia yang berjumlah 508 kabupaten/kota yang terdiri dari 415 kabupaten dan 98 kota. Teknik pengambilan sampel yang digunakan adalah nonprobability sampling yaitu purposive sampling. Kriteria sampel yang digunakan adalah pemerintah daerah yang mempunyai website resmi yang dapat diakses; website pemerintah daerah memiliki konten terkait transparansi anggaran; dan laporan target dan realisasi anggaran serta neraca keuangan tersedia pada laman resmi Dirjen Perimbangan Keuangan Kementerian Keuangan. Berdasarkan kriteria tersebut, dari 508 kabupaten/kota di Indonesia, 9 kabupaten/kota belum memiliki website resmi, 32 website mengalami gangguan dan tidak bisa diakses, 259 website kabupaten/kota tidak memiliki menu terkait transparansi, dan 5 pemerintah kabupaten/kota yang neraca keuangannya tidak tersedia pada laman resmi Dirjen Perimbangan Keuangan Kementerian Keuangan sehingga terpilih 203 sampel kabupaten/kota yang dianalisis.

Variabel independen dalam penelitian ini adalah ukuran pemda (SIZE), leverage (LEV), dan kinerja keuangan (KK). Ukuran pemda diukur dengan menggunakan logaritma natural atas total aset pemerintah daerah seperti pada penelitian (Trisnawati \& Achmad, 2014). Pengukuran leverage mengacu pada penelitian (Nosihana \& Yaya, 2016) dimana leverage diukur menggunakan rasio total kewajiban dengan total aset yang dimiliki oleh pemda. Kinerja keuangan diukur dengan rasio keuangan pada pemerintah daerah yang dikemukakan oleh Halim (2004) yaitu rasio kemandirian keuangan daerah. Variabel dependen dalam penelitian ini adalah Internet Financial Reporting (IFR). IFR dihitung berdasarkan scoring indeks ketersediaan informasi keuangan sesuai yang tertuang di dalam ketentuan Instruksi Mendagri Nomor 188.52/1797/SJ Tahun 2012 pada situs resmi setiap Pemda di Indonesia yang terdiri dari 12 item. Sedangkan variabel moderasi pada penelitian ini adalah opini audit (OPINI) yang diukur dengan menggunakan skala nominal/dummy.

Teknik analisis yang digunakan dalam penelitian ini ada 2 yaitu analisis regresi majemuk dan moderated regression analysis (MRA) yang diolah dengan bantuan program SPSS. Model regresi dalam penelitian ini ditunjukkan dengan persamaan sebagai berikut.

$$
\begin{array}{ll}
Y=\alpha+\beta_{1} X_{1}+\beta_{2} X_{2}+\beta_{3} X_{3}+\varepsilon & \\
Y=\alpha+\beta_{1} X_{1}+\beta_{2} X_{2}+\beta_{3} X_{3}+\beta_{4} Z+\beta_{5}\left(X_{1} Z\right)+\beta_{6}\left(X_{2} Z\right)+\beta_{7}\left(X_{3} Z\right)+\varepsilon \\
\text { Keterangan : } \\
Y \quad=\text { Internet Financial Reporting (IFR) } \\
a \quad=\text { Konstanta } \\
X_{1} \quad=\text { Ukuran Pemda (SIZE) } \\
X_{2} \quad=\text { Leverage (LEV) } \\
X_{3} \quad=\text { Kinerja Keuangan (KK) } \\
Z \quad=\text { Opini Audit } \\
\beta_{1-} \beta_{7} \quad=\text { Koefisien regresi variabel bebas } X_{1}-X_{7} \\
\varepsilon & =\text { error }
\end{array}
$$




\section{HASIL DAN PEMBAHASAN}

Data yang digunakan adalah data sekunder yang diperoleh dari laman resmi Kementerian Dalam Negeri, Direktorat Jenderal Perimbangan Keuangan Kementerian Keuangan, dan BPK RI serta hasil observasi pada website pemerintah Kabupaten dan Kota di Indonesia. Data tersebut antara lain data pemerintah kabupaten dan kota di Indonesia, laporan target dan realisasi APBD tahun anggaran 2017, neraca pemerintah kabupaten dan kota tahun 2017, dan Ikhtisar Hasil Pemeriksaan BPK RI. Pengujian dilakukan pada 203 pemerintah kabupaten dan kota di Indonesia.

Sebelum analisis menggunakan PLS-SEM terlebih dahulu dilakukan analisis statistik deskriptif data guna mendeskripsikan data sampel. Hasil analisis statistik deskriptif menunjukkan nilai ukuran pemda terendah adalah 27,1940 dan nilai tertinggi 31,0308 dengan rata-rata 28,6339 dan standar deviasi sebesar 0,7369, ini menunjukkan bahwa variabel ukuran pemda memiliki sebaran yang kecil karena standar deviasi lebih kecil dari nilai rata-rata. Nilai terendah leverage adalah sebesar 0,0000 dan nilai tertinggi 0,1570 dengan ratarata sebesar 0, 0176 dan standar deviasi sebesar 0,0226, ini menunjukkan bahwa variabel leverage memiliki sebaran yang cukup besar karena standar deviasi lebih besar dari rata-rata. Nilai kinerja keuangan terendah adalah 0,4600 dan nilai tertinggi 54,0600 dengan nilai rata-rata 17,1999 dan standar deviasi sebesar 11,2813, ini menunjukkan bahwa variabel kinerja keuangan memiliki sebaran yang kecil karena standar deviasi lebih kecil dari nilai rata-rata. Nilai terendah opini audit adalah 0,000 dan nilai tertinggi 1,000 dengan rata-rata 0,8128 dan standar deviasi sebesar 0,3910, ini menunjukkan bahwa variabel opini audit memiliki sebaran yang kecil karena standar deviasi lebih kecil dari nilai ratarata. IFR memiliki nilai terendah 0,000 dan nilai tertinggi 100,000 dengan ratarata 12,3151 dan standar deviasi sebesar 20,6855, ini menunjukkan bahwa variabel IFR memiliki sebaran yang cukup besar karena standar deviasi lebih besar dari rata-rata.

Pengujian data dalam penelitian ini menggunakan 2 regresi yaitu analisis regresi majemuk dan moderated regression analysis (MRA) melalui software SPSS 18.0 for Windows, diperoleh hasil yang ditunjukan pada tabel 1 .

Tabel 1. Hasil Analisis Regresi Majemuk

\begin{tabular}{|c|c|c|c|c|c|c|}
\hline \multirow[t]{2}{*}{ Model } & & \multicolumn{2}{|c|}{$\begin{array}{c}\text { Unstandardized } \\
\text { Coefficients }\end{array}$} & \multirow{2}{*}{$\begin{array}{c}\text { Standardized } \\
\text { Coefficients }\end{array}$} & \multirow[b]{2}{*}{$\mathrm{T}$} & \multirow[b]{2}{*}{ Sig } \\
\hline & & B & $\begin{array}{l}\text { Std. } \\
\text { Error }\end{array}$ & & & \\
\hline \multirow[t]{4}{*}{1} & Konst & -179.564 & 71.105 & & -2.525 & 0.012 \\
\hline & SIZE & 6.394 & 2.560 & 0.228 & 2.498 & 0.013 \\
\hline & LEV & 101.538 & 59.729 & 0.111 & 1.700 & 0.091 \\
\hline & KK & 0.408 & 0.165 & 0.222 & 2.475 & 0.014 \\
\hline R Square & & & & & & 0.194 \\
\hline F Statistik & & & & & & 15.989 \\
\hline Signifikansi & & & & & & 0.000 \\
\hline
\end{tabular}

Sumber: Data Penelitian, 2019 
Berdasarkan hasil analisis regresi majemuk seperti yang disajikan pada Tabel 1, maka persamaan strukturalnya adalah sebagai berikut :

$$
Y=-179,564+6,394 X_{1}+101,538 X_{2}+0,408 X_{3}+\varepsilon
$$

Nilai koefisien regresi dari variabel ukuran pemda $\left(X_{1}\right)$ yaitu 6,394 dengan signifikansi 0,013. Hal ini berarti ukuran pemda mempunyai pengaruh positif terhadap Internet Financial Reporting. Nilai koefisien regresi dari variabel leverage $\left(\mathrm{X}_{2}\right)$ yaitu 101,538 dengan signifikansi 0,091. Hal ini berarti leverage tidak berpengaruh terhadap Internet Financial Reporting. Nilai koefisien regresi dari variabel kinerja keuangan $\left(X_{3}\right)$ yaitu 0,408 dengan signifikansi 0,014 . Hal ini berarti kinerja keuangan mempunyai pengaruh positif terhadap Internet Financial Reporting.

Regresi kedua dalam penelitian ini adalah moderated regression analysis (MRA). Hasil analisis MRA dapat dilihat pada Tabel 2.

Tabel 2.Hasil Moderated Regression Analysis

\begin{tabular}{|c|c|c|c|c|c|}
\hline & \multicolumn{2}{|c|}{$\begin{array}{l}\text { Unstandardized } \\
\text { Coefficients }\end{array}$} & $\begin{array}{l}\text { Standardized } \\
\text { Coefficients }\end{array}$ & \multirow[b]{2}{*}{$\mathrm{T}$} & \multirow[b]{2}{*}{ Sig. } \\
\hline & B & $\begin{array}{l}\text { Std. } \\
\text { Error }\end{array}$ & Beta & & \\
\hline Konstanta & -124.414 & 128.712 & & -0.967 & 0.335 \\
\hline SIZE & 4.221 & 4.643 & 0.150 & 0.909 & 0.364 \\
\hline LEV & 139.120 & 98.560 & 0.152 & 1.412 & 0.160 \\
\hline KK & 0.584 & 0.338 & 0.318 & 1.728 & 0.086 \\
\hline OPINI & -81.484 & 154.939 & -1.540 & -0.526 & 0.600 \\
\hline Interaksi, $\mathrm{X}_{1}, \mathrm{Z}$ & 3.173 & 5.584 & 1.720 & 0.568 & 0.571 \\
\hline Interaksi, $\mathrm{X}_{2}, \mathrm{Z}$ & -43.015 & 124.856 & -0.039 & -0.345 & 0.731 \\
\hline Interaksi, $\mathrm{X}_{3}, \mathrm{Z}$ & -0.257 & 0.388 & -0.149 & -0.661 & 0.509 \\
\hline R Square & & & & & 0.203 \\
\hline F Statistik & & & & & 7.090 \\
\hline Signifikansi & & & & & 0.000 \\
\hline
\end{tabular}

Sumber: Data Penelitian, 2019

Berdasarkan hasil moderated regression analysis seperti yang disajikan pada tabel 4, maka persamaan strukturalnya adalah sebagai berikut :

$$
\begin{aligned}
Y= & -124,414+4,221 X_{1}+139,120 X_{2}+0,584 X_{3}-81,484 Z+3,173 X_{1} Z- \\
& 43,015 X_{2} Z-0,257 X_{3} Z+\varepsilon
\end{aligned}
$$

Konstanta regresi sebesar -124.414 menunjukkan bahwa apabila nilai ukuran pemda, leverage, kinerja keuangan, dan opini audit sama dengan nol, maka nilai Internet Financial Reporting akan sebesar -124,414 satuan. Koefisien regresi ukuran pemda sebesar 4,221 (positif). Hal ini menunjukkan bahwa apabila ukuran pemda meningkat sebesar 1 satuan, maka variabel Internet Financial Reporting akan meningkat dengan asumsi variabel lain konstan. Koefisien regresi leverage sebesar 139,120 (positif). Hal ini menunjukkan bahwa apabila leverage meningkat sebesar 1 satuan, maka variabel Internet Financial Reporting akan meningkat dengan asumsi variabel lain konstan. Koefisien regresi kinerja keuangan sebesar 0,584 (positif). Hal ini menunjukkan bahwa apabila kinerja keuangan meningkat sebesar 1 satuan, maka variabel Internet Financial Reporting akan meningkat dengan asumsi variabel lain konstan. 
Nilai koefisien regresi dari variabel interaksi ukuran pemda $\left(X_{1}\right)$ dengan opini audit (Z) bernilai positif yaitu 3,173 dan koefisien regresi ukuran pemda $\left(\mathrm{X}_{1}\right)$ bernilai positif yaitu 4,221 dengan tingkat signifikansi 0,571 . Hal ini menunjukkan bahwa opini audit tidak memoderasi pengaruh ukuran pemda terhadap Internet Financial Reporting. Nilai koefisien regresi dari variabel interaksi leverage $\left(X_{2}\right)$ dengan opini audit $(Z)$ bernilai negatif yaitu $-43,015$ dan koefisien regresi leverage $\left(X_{2}\right)$ bernilai positif yaitu 139,120 dengan tingkat signifikansi 0,731. Hal ini menunjukkan bahwa opini audit tidak memoderasi pengaruh leverage terhadap Internet Financial Reporting. Nilai koefisien regresi dari variabel interaksi kinerja keuangan $\left(X_{3}\right)$ dengan opini audit $(Z)$ bernilai negatif yaitu $-0,257$ dan koefisien regresi kinerja keuangan $\left(X_{3}\right)$ bernilai positif yaitu 0,584 dengan tingkat signifikansi 0,509. Hal ini menunjukkan bahwa opini audit tidak memoderasi pengaruh kinerja keuangan terhadap Internet Financial Reporting.

Koefisien determinasi $\left(\mathrm{R}^{2}\right)$ digunakan untuk mengetahui dan mengukur kemampuan model dalam menerangkan variasi variabel independen. Hasil uji pada analisis regresi majemuk memberikan hasil dimana diperoleh nilai $\mathrm{R}^{2}$ sebesar 0,194. Ini berarti variasi Internet Financial Reporting pada pemda di Indonesia dapat dipengaruhi secara signifikan oleh variabel ukuran pemda $\left(X_{1}\right)$, variabel leverage $\left(X_{2}\right)$, dan variabel kinerja keuangan $\left(X_{3}\right)$ sebesar 19,4\% sedangkan sisanya sebesar $80,6 \%$ dijelaskan oleh faktor-faktor lain. Pada moderated regression analysis Tabel 4 diperoleh $\mathrm{R}^{2}$ sebesar 0,203. Ini berarti variasi Internet Financial Reporting pada pemda di Indonesia dapat dipengaruhi secara signifikan oleh variabel ukuran pemda $\left(X_{1}\right)$, variabel leverage $\left(X_{2}\right)$, variabel kinerja keuangan $\left(X_{3}\right)$, variabel interaksi antara ukuran pemda $\left(X_{1}\right)$ dengan opini audit $(Z)$, variabel interaksi antara leverage $\left(X_{2}\right)$ dengan opini audit $(Z)$, dan variabel interaksi antara kinerja keuangan $\left(X_{3}\right)$ dengan opini audit $(Z)$ sebesar 20,3\% dan sisanya dijelaskan oleh faktor lain.

Hasil uji $\mathrm{F}$ menunjukkan bahwa nilai signifikansi $\mathrm{P}$ value 0,000 yang lebih kecil dari $\alpha=0,05$, ini berarti model yang digunakan pada penelitian ini adalah layak. Hasil ini memberikan makna bahwa seluruh variabel independen yaitu ukuran pemda $(X 1)$, leverage $(X 2)$, kinerja keuangan $\left(X_{3}\right)$, opini audit $(Z)$, variabel interaksi antara ukuran pemda dengan opini audit $\left(\mathrm{X}_{1} . Z\right)$, variable interaksi antara leverage dengan opini audit $\left(\mathrm{X}_{2} . \mathrm{Z}\right)$ dan variabel interaksi antara kinerja keuangan dengan opini audit $\left(X_{3} . Z\right)$ mampu memprediksi atau menjelaskan fenomena Internet Financial Reporting. Hal ini berarti model dapat digunakan untuk analisa lebih lanjut atau dengan kata lain model dapat digunakan untuk memproyeksikan karena hasil goodness of fitnya baik dengan nilai signifikansi P value 0,000. 
Tabel 5. Hasil Uji Kelayakan Model (Uji F)

\begin{tabular}{lllllll}
\hline Model & & $\begin{array}{l}\text { Sum } \\
\text { Square }\end{array}$ & df & Mean Square F & Sig. \\
\hline 1 & Regression & 16787.328 & 3 & 5595.776 & 15.989 & 0.000 \\
& Residual & 69646.512 & 199 & 349.982 & & \\
& Total & 86433.840 & 202 & & & \\
\hline
\end{tabular}

Sumber: Data Penelitian, 2019

Hipotesis pertama tentang ukuran pemda berpengaruh positif terhadap Internet Financial Reporting, dimana hipotesis diterima. Hasil penelitian ini sejalan dengan stewardship theory dimana pemerintah daerah sebagai steward lebih termotivasi untuk mencapai tujuan organisasi. Dalam hal ini, pemerintah daerah diharapkan dapat mewujudkan transparansi terhadap masyarakat sesuai dengan harapan dan kepercayaan yang telah diberikan oleh masyarakat. Hasil penelitian ini sejalan dengan penelitian terdahulu yang dilakukan oleh (García \& García-García, 2010), (Medina, 2012), (Trisnawati \& Achmad, 2014) dan (Diani, 2016) yang menemukan bahwa ukuran pemerintah daerah berpengaruh terhadap Internet Financial Reporting. Pemerintah daerah yang besar akan memiliki total aset yang besar pula. Jumlah total aset yang besar memungkinkan pemerintah daerah untuk meningkatkan investasi pada sarana dan prasarana terkait transparansi seperti melakukan pengembangan pada website resmi pemerintah daerah. Melalui website, pemerintah daerah dapat memenuhi kewajibannya akan transparansi kepada masyarakat dengan lebih cepat dan hemat biaya.

Hipotesis kedua tentang leverage berpengaruh positif terhadap Internet Financial Reporting, dimana hipotesis ditolak. Hasil penelitian ini mendukung penelitian yang dilakukan oleh (Sinaga \& Probowo, 2011), (Prabowo, 2016), (Nosihana \& Yaya, 2016) dan (Diani, 2016) yang menemukan bahwa Internet Financial Reporting tidak dipengaruhi oleh leverage. Namun, hasil ini berbeda dengan penelitian yang dilakukan oleh (García \& García-García, 2010), (Sutaryo et al., 2013) serta (Trisnawati \& Achmad, 2014) yang menunjukkan bahwa leverage berpengaruh positif terhadap Internet Financial Reporting. Penelitian (Laswad et al., 2005) menemukan bahwa Internet Financial Reporting merupakan sarana yang efektif dalam membantu pemerintah daerah di New Zealand untuk menyediakan informasi terkait penggunaan dana dan kesanggupan pemerintah daerah untuk mengembalikan dana yang dipinjam kepada kreditor. Sebaliknya, di Indonesia pemerintah daerah dengan leverage tinggi tidak mempublikasikan informasi keuangan melalui internet karena pemerintah daerah dengan leverage tinggi dianggap memiliki kinerja yang buruk. Hal ini tidak sejalan dengan signalling theory dimana pemerintah seharusnya memberikan sinyal-sinyal positif kepada pihak eksternal. Pemerintah daerah justru membatasi informasi yang diberikan kepada pihak eksternal guna menghindari sorotan perhatian dari kreditor.

Hipotesis ketiga tentang kinerja keuangan berpengaruh positif terhadap Internet Financial Reporting, dimana hipotesis diterima. Hasil penelitian ini 
sejalan dengan konsep signalling theory dimana pemerintah daerah dengan kinerja keuangan cenderung melakukan Internet Financial Reporting. Hasil penelitian ini mendukung penelitian (Hiola et al., 2015) yang menunjukkan bahwa semakin baik kinerja keuangan pemerintah daerah maka pemerintah daerah juga akan semakin patuh dalam melakukan pengungkapan informasi keuangan di website resminya. Sebaliknya, penelitian ini tidak sejalan dengan penelitian (Puspita \& Martani, 2012) yang menemukan bahwa kinerja pemerintah daerah tidak berpengaruh terhadap pengungkapan informasi keuangan di website. Pemerintah daerah yang memiliki kinerja keuangan yang tinggi akan mengungkapan informasi keuangan di website resminya.

Hipotesis keempat tentang opini audit memperkuat pengaruh ukuran pemda terhadap Internet Financial Reporting, dimana hipotesis ditolak. Hasil penelitian ini tidak sejalan dengan signalling theory yang menjelaskan bahwa pemerintah daerah akan mengirimkan berbagai sinyal positif kepada masyarakat. Opini audit yang baik menunjukkan bahwa pemerintah daerah telah menjalankan amanat masyarakat dengan baik pula, akan tetapi opini audit tidak mampu memperkuat hubungan antara ukuran pemerintah daerah dengan Internet Financial Reporting. Pemerintah daerah dengan ukuran yang besar memiliki total aset yang besar pula. Semakin besar aset yang dimiliki pemerintah daerah maka akan semakin sulit pengelolaannya seperti pencatatan atas aset - aset daerah. Hal ini dapat menjadi penyebab pemerintah daerah enggan mengungkapkan informasi keuangan pada website resminya. Opini audit WTP tidak selalu mengindikasikan bahwa akuntabilitas pemerintah daerah telah benar - benar baik sehingga opini audit tidak dapat memperkuat hubungan antara ukuran pemerintah daerah dengan Internet Financial Reporting.

Hipotesis kelima tentang opini audit memperkuat pengaruh leverage terhadap Internet Financial Reporting, dimana hipotesis ditolak. Berdasarkan konsep signalling theory, pemerintah daerah akan memberikan sinyal-sinyal terkait kesanggupan untuk mengembalikan dana yang dipinjam dengan mengungkapkan informasi keuangan melalui website pemerintah daerah. Informasi keuangan yang dipublikasikan harus memiliki kualitas yang baik yang dibuktikan dengan mendapatkan opini Wajar Tanpa Pengecualian dari BPK. Akan tetapi, hasil penelitian ini tidak sejalan dengan konsep signalling theory. Pemerintah daerah yang memiliki leverage tinggi justru tidak mempublikasikan informasi keuangan di website resminya. Hal ini disebabkan pemerintah daerah dengan leverage tinggi dianggap memiliki kinerja yang buruk sehingga pemerintah daerah cenderung tidak mengungkapkan informasi keuangan agar tidak menjadi sorotan kreditur. Dengan kata lain, pemerintah daerah belum sepenuhnya terbuka kepada pihak eksternal seperti kreditur.

Hipotesis keenam tentang opini audit memperkuat pengaruh kinerja keuangan terhadap Internet Financial Reporting, dimana hipotesis ditolak. Hasil 
penelitian ini tidak sejalan dengan penelitian yang dilakukan (Hiola et al., 2015) yang menemukan bahwa opini audit dapat memoderasi pengaruh kinerja keuangan terhadap kepatuhan pengungkapan informasi keuangan pemerintah daerah di website. Pemerintah daerah dengan kinerja yang baik serta memperoleh opini Wajar Tanpa Pengecualian tidak serta merta mengungkapkan informasi keuangan pada website resminya. Hal ini bisa disebabkan oleh perbedaan pemahaman pemerintah daerah akan pemanfaatan teknologi informasi seperti internet sebagai media transparansi informasi keuangan. Pemerintah daerah yang memperoleh opini WTP untuk LKPD Tahun 2017 mencapai 76\%, yang berarti sebagian besar pemerintah daerah di Indonesia telah menyajikan informasi secara wajar sesuai dengan SAP dan SAK dalam laporan keuangan pemerintah daerah. Akan tetapi, kinerja keuangan sebagian besar pemerintah daerah di Indonesia jika dilihat dari tingkat kemandirian daerah termasuk dalam kategori rendah sekali. Artinya, kemampuan pemerintah daerah dalam membiayai sendiri kegiatan pemerintahan, pembangunan, dan pelayanan kepada masyarakat sangat rendah. Hal ini menyebabkan pemerintah daerah cenderung tidak mengungkapkan informasi keuangan pada website resmi pemerintah daerah meskipun memperoleh opini WTP atas Laporan Keuangan Pemerintah Daerah.

Temuan dari penelitian ini dapat memperjelas konsep signalling theory dimana Internet Financial Reporting merupakan media bagi pemerintah daerah untuk memberikan sinyal positif kepada masyarakat terkait akuntabilitas dan transparansi informasi keuangan. Temuan penelitian ini juga memperjelas konsep stewardship theory. Semakin besar ukuran pemerintah daerah maka akan semakin besar asimetri informasi yang tercipta. Melalui Internet Financial Reporting pemerintah daerah dapat meminimalisir asimetri informasi dan mewujudkan transparansi sesuai dengan amanat yang telah diberikan oleh masyarakat.

Hasil penelitian ini dapat digunakan oleh pemerintah daerah sebagai bahan rujukan dalam upaya mengembangkan website resminya guna menyampaikan informasi khususnya informasi keuangan. Pemerintah daerah kabupaten dan kota yang masih memiliki tingkat pengungkapan yang rendah dapat mencontoh pemerintah daerah yang memiliki tingkat pengungkapan tinggi dalam mengelola informasi-informasi keuangan yang akan disajikan pada website resmi pemerintah daerah. Hasil penelitian ini juga dapat dijadikan tolak ukur dan evaluasi terkait Internet Financial Reporting dalam meningkatkan transparansi pemerintah daerah sebagaimana diatur dalam beberapa regulasi seperti Undang-Undang Republik Indonesia No. 14 Tahun 2008 tentang Keterbukaan Informasi Publik dan Instruksi Mendagri No. 188.52/179/SJ Tahun 2012 tentang Peningkatan Transparansi Pengelolaan Anggaran Daerah. Pemerintah pusat dapat memberikan sanksi kepada pemerintah daerah yang tidak mengungkapkan informasi pengelolaan anggaran daerah di website resminya serta memberikan reward (penghargaan) kepada pemerintah daerah 
yang mengungkapkan informasi keuangan di website resminya sesuai dengan Instruksi Menteri Dalam Negeri No. 188.52/179/SJ Tahun 2012 tentang Peningkatan Transparansi Pengelolaan Anggaran Daerah.

\section{SIMPULAN}

Ukuran pemerintah daerah berpengaruh positif dan signifikan terhadap Internet Financial Reporting pada pemerintah daerah di Indonesia. Leverage tidak berpengaruh secara signifikan terhadap Internet Financial Reporting pada pemerintah daerah di Indonesia. Kinerja keuangan berpengaruh positif dan signifikan terhadap Internet Financial Reporting pada pemerintah daerah di Indonesia. Opini audit tidak berpengaruh secara signifikan terhadap hubungan ukuran pemerintah daerah dengan Internet Financial Reporting. Opini audit tidak berpengaruh secara signifikan terhadap hubungan leverage dengan Internet Financial Reporting pada pemerintah daerah di Indonesia. Opini audit tidak berpengaruh secara signifikan terhadap hubungan kinerja keuangan dengan Internet Financial Reporting pada pemerintah daerah di Indonesia.

Dari hasil penelitian yang telah diuraikan, maka dapat disarankan bagi penelitian selanjutnya dapat menambahkan variabel lain yang memiliki keterkaitan dengan Internet Financial Reporting seperti kompetisi politik, tipe pemerintah daerah, kekayaan pemerintah daerah, dan evaluasi kinerja pemerintah daerah. Penelitian selanjutnya juga dapat menambah indikator penelitian untuk variabel kinerja keuangan seperti rasio efisiensi dan rasio belanja modal serta mengembangkan pengukuran tingkat Internet Financial Reporting dengan menambah jumlah indeks skoring yang lebih menunjukkan jumlah informasi yang disampaikan pada website pemerintah daerah seperti informasi kinerja dan berita keuangan.

\section{REFERENSI}

Diani, R. P. (2016). Analisis Determinan Pelaporan Keuangan di Internet oleh Pemerintah daerah di Indonesia.

Donaldson, L., \& Davis, J. H. (1991). Stewardship Theory or Agency Theory: CEO Governance and Shareholder Returns. Australian Journal of Management, 16 (1), 49-64. https:/ / doi.org/10.1177/031289629101600103

García, A. C., \& García-García, J. (2010). Determinants of online reporting of accounting information by Spanish local government authorities. Local Government Studies, 36(5), 679-695. https:/ / doi.org/10.1080/03003930.2010.506980

Hiola, Y., Rosidi, \& Mulawarman, A. D. (2015). Political Environment in the Effect of the Regional Government Financial Performance on Disclosure of Financial Information on Website. Journal of Economics, Business $\mathcal{E}$ Accountancy Ventura, 19(1), 27-36.

Kholifah, D. W. (2019). Determinan Praktik Internet Financial Reporting (IFR) dalam Website Pemerintah Daerah (Studi pada Pemerintah Kabupaten/Kota di Indonesia Tahun 2016-2017).

Laswad, F., Fisher, R., \& Oyelere, P. (2005). Determinants of voluntary Internet financial reporting by local government authorities. Journal of Accounting and 
Public

Policy,

$24(2)$

$101-121$

https://doi.org/10.1016/j.jaccpubpol.2004.12.006

Medina, F. (2012). Faktor-Faktor yang Mempengaruhi Transparansi Informasi Keuangan pada Situs Resmi Pemerintah Daerah di Indonesia.

Nosihana, A., \& Yaya, R. (2016). Internet Financial Reporting dan Faktor-Faktor yang Mempengaruhinya Pada Pemerintah Kota dan Kabupaten Di Indonesia. Jurnal Dinamika Akuntansi Dan Bisnis, 3(2), 89-104. https://doi.org/10.24815/jdab.v3i2.5389

Prabowo, D. W. A. (2016). Publikasi Laporan Keuangan Pemerintah Daerah (LKPD) Melalui Internet (IFLGR) Dan Faktor-Faktor Yang Mempengaruhi. Jurnal Manajemen Dan Bisnis Media Ekonomi, XVI(1), 114-129.

Purwanti, R. E. (2017). Pengaruh Kondisi Keuangan, Tingkat Ketergantungan, Rasio Belanja Modal dan Evaluasi Kinerja terhadap Transparansi Internet Financial Reporting (Studi pada Pemerintah Kabupaten/Kota di Indonesia). Universitas Mataram.

Puspita, R., \& Martani, D. (2012). Analisis Pengaruh Kinerja dan Karakteristik Pemda terhadap Tingkat Pengungkapan dan Kualitas Informasi dalam Website Pemda. Simposium Nasional Akuntansi XV. https://doi.org/10.7775/rac.v84.i1.7932

Sinaga, Y. F., \& Probowo, T. J. W. (2011). Analisis Faktor-Faktor yang Mempengaruhi Pelaporan Keuangan di Internet Secara Sukarela oleh Pemerintah Daerah. Jurnal Universitas Diponegoro, 1-33.

Styles, A. K., \& Tennyson, M. (2007). The Accessibility of Financial Reporting of U.S. Municipalities on The Internet. Journal of Public Budgeting, Accounting and Financial Management, 19(1), 56-92.

Sutaryo, Rahman, A., \& Budiatmanto, A. (2013). Determinan Internet Financial Reporting Di Indonesia. Simposium Nasional Akuntansi XVI, 1299-1323.

Trisnawati, M. D., \& Achmad, K. (2014). Determinan Publikasi Laporan Keuangan Pemerintah Daerah Melalui Internet. Simposium Nasional Akuntansi XVII.

Verawaty. (2015). Determinan Aksesibilitas Internet Financial Reporting melalui E-Government Pemerintah Daerah di Indonesia. Simposium Nasional Akuntansi.

Wau, I., \& Ratmono. (2015). Analisis Faktor-Faktor Yang Mempengaruhi Ketersediaan Dan Keteraksesan Internet Financial. Diponegoro Journal of Accounting, 4(2002), 1-12.

Wulandari, N. A., \& Sulardi, S. (2018). Pengaruh Karakteristik Daerah, Temuan, Dan Opini Audit (Studi Empiris Pada Website Pemda di Indonesia). Akuntansi Dewantara, 2(1), 69-82. https:// doi.org/10.29230/ad.v2i1.2477

Xiao, Jones, \& Lymer. (2005). A Conceptual Framework for Investigating the Impact of the Internet on Corporate Financial Reporting. The International Journal of Digital Accounting Research, 5(September), 131-169. https://doi.org/10.4192/1577-8517-v5_4 